non-infringing acts, while reception over huge master receiving sets connected to hundreds of loudspeakers stands nearer the opposite pole in the realm of the infringing. ${ }^{73}$

Already, in Louis v. Richman, ${ }^{74}$ a Pennsylvania court seems to have adopted this criterion by refusing to enjoin the showing of a sports telecast in commercial establishments employing screens no larger than eighteen by twentyfour inches and making no direct admission charge. Certainly, the judge's willingness to prohibit the use of television in a large hotel, although not in a bar and grill (a "poor man's club," as he called it) represents a justifiable restriction of the copyright owner's already over-extended power. It is submitted that, if courts follow the lead of Louis v. Richman ${ }^{75}$ and the Hotel Statler cases in abandoning the absolutistic principle of multiple performance before they are irrevocably committed, the burden of copyright monopolies will not fall so heavily upon the society which grants them.

\title{
RACIAL VIOLENCE AND CIVIL RIGHTS LAW ENFORCEMENT
}

The history of racial violence in the United States, filled with accounts of costly race riots and lynchings, is uncomfortably familiar. Increasingly urgent is the question whether a great body of civil rights law must remain unenforced because of the specter of such violence. ${ }^{2}$

73 Society of European S.A.A.C. v. New York Hotel Statler, I9 F. Supp. I, 2-3 (S.D.N.Y., 1937), contains a most impressive description of the trouble and expense to which the Hotel Pennsylvania went in "piping" broadcasts to its I9oo guest rooms.

74 Equity No. I803, Pa. C.P. (Philadelphia, June 23, 1948). See Louis v. Friedman, Equity No. I804, Pa. C.P. (Philadelphia, June 23, r948) (injunction against exhibition of same telecast in a motion picture theater); Louis v. California Products, N.Y. S. Ct. (June 24, I948) (same, against a ballroom operator); Twentieth Century Sporting Club, Inc. v. Mass. Charitable Mechanics Association, Equity No. 60230, Mass. Super. Ct. (June 22, I948) (same); and National Broadcasting Co. pamphlet entitled: "Proceedings in Philadelphia Actions in C.P. No. I, June Term, I948, to enjoin commercial uses of the Louis-Walcott Fight."

75 Equity No. I803, Pa. C.P. (Philadelphia, June 23, r948), unreported.

I Consult Myrdal, An American Dilemma 550-569 (I944); Chicago Commission on Race Relations, The Negro in Chicago (r922); Lee and Humphrey, Race Riot (1943); Raper, The Tragedy of Lynching (I933).

Racial violence is usually treated as an unmitigated evil. However, some observers feel that it may have positive value as a catalyst for progress in race relations. Myrdal, Social Trends in America and Strategic Approaches to the Negro Problem, 9 Phylon I96, 208 (1948). It may also provide an opportunity for minority group resistance to aggression, thus encouraging minority group members to establish positive identification with their group through collective action. Fisher, The Problem of Violence, Observations on Race Conflict in Los Angeles I7, 18 (American Council on Race Relations, I947); Johnson, Patterns of Negro Segregation 3I3-I5 (I943). Compare Sartre, Anti-Semite and Jew 59-I4I (I948) and Broyard, Portrait of the Inauthentic Negro, ro Commentary, No. I, at 56 (July, r950).

2 Mangum, The Legal Status of the Negro $26 \mathrm{ff}$. (r940) contains a summary of the civil rights legislation passed in many northern states after post-Civil-War federal civil rights legislation was held unconstitutional. Much of the state legislation has ample enforcement provisions. An Illinois statute, e.g., provides that all persons are entitled to full and equal enjoyment of establishments maintained for public use (hotels, restaurants, department stores, 
The practical problems of law enforcement have been thrown into sharp relief by postwar agitation for civil rights legislation ${ }^{3}$ and by recent decisions which have seriously weakened the constitutional foundations of racial segregation. Sweatt v. Painter, ${ }^{4}$ McLaurin v. Oklahoma State Regents,${ }^{5}$ and Henderson v. United States, ${ }^{6}$ all decided in 1950 by the Supreme Court, represented the most sustained attack yet made on the principle of racial segregation, constitutionally embodied in the "separate but equal" doctrine. The decisions attenuated that doctrine and further vitiated what remains of the principal case under attack, Plessy v. Ferguson.7

But it is clear that the passage of civil rights legislation and the judicial extension of constitutional protections are but first steps towards vitalizing democratic principle in the field of race relations. Even if an asserted right to be free from segregation is given legal recognition, proof of its infringement may be so difficult that the right is effectively denied. ${ }^{8}$ Or the right can be made a dead letter if government fails to provide for vigorous law enforcement.

This note focuses on one aspect of the problem of enforcing civil rights law. The concrete question is whether racial violence is an inevitable consequence of protecting individual rights which come into conflict with established patterns of racial segregation. ${ }^{9}$ The question calls for an examination of recent situations

railroads, etc.). Ill. Rev. Stat. (r949) c. $38, \S$ I25. Remedies include (x) recovery of damages by persons aggrieved by violations of the statute, ibid., at $\S$ I 26 ; (2) criminal penalties, ibid., at $\S 126$; and $(3)$ the declaration of establishments violating the statute to be public nuisances whose operations can be enjoined, ibid., at $\S$ I28a.

${ }^{3}$ Consult Report of the President's Committee on Civil Rights, To Secure these Rights (1947).

$$
{ }^{4} 339 \text { U.S. } 629 \text { (r950). } \quad{ }^{5} 339 \text { U.S. } 637 \text { (I950). } \quad{ }^{6} 339 \text { U.S. 8I6 (I950). }
$$

${ }_{7} x_{3}$ U.S. 537 ( 1896$)$. In each of the $195^{\circ}$ cases, the finding of inequality and discrimination violative of the Fourteenth Amendment was so close to being based on the simple fact of segregation as to presage imminent overruling of the Plessy case. Cf. Frank, The United States Supreme Court: 1949-r950, I8 Univ. Chi. L. Rev. x, 33-37 (r950).

${ }^{8}$ An American Legal Dilemma-Proof of Discrimination, I7 Univ. Chi. L. Rev. I07 (I949).

- The proponents of segregation make two arguments connected with violence. The first, dealt with here, is that disturbing existing patterns of segregation is likely to lead to violence. The classic rebuttal of the second notion, that segregation tends to prevent racial conflict, remains Justice Harlan's dissent in Plessy v. Ferguson, $x 6_{3}$ U.S. 537, 552, 560 (I896). See also Edgerton, J., dissenting in Hurd v. Hodge, I62 F. 2d 233, 242, 243 (App. D.C., I947), whose view was later upheld by the Supreme Court in Hurd v. Hodge, 334 U.S. 24 (r948). In passing on the eligibility of Negroes to hold public office, a Georgia court once said that "[i]f ... laws are unfair, unjust, unequal, they will breed discontent and disorder, and it is better for the peace and good order of society that all shall have equal rights." White v. Clements, $39 \mathrm{Ga}$. 232, 269 (1869). See also Hurd v. Hodge, 334 U.S. 24 (I948), Brief for Petitioners at 68-7I.

That segregation tends to promote tension and violence seems clearest in the case of housing. Weaver, Race Restrictive Housing Covenants, 20 Journ. of Land and Utility Economics $183,187,189, x_{93}$ (I944). Reporting on the $x_{943}$ Detroit race riot, a Wayne University sociologist observed that interracial neighborhoods were conspicuously free from disturbances. Lee and Humphrey, Race Riot I 7, 97, II6, I30, I40 (1943). Specialists agree that tensions are likely to run highest along the borders of residential ghettos. Lohman, Police and Minority Groups 2r, 22 (I947). 
in which the problem has arisen and a consideration of new developments in the arts of law enforcement. ${ }^{\mathrm{x}}$

In recent years many American communities have faced the danger of racial violence when existing patterns of segregation were challenged. The experiences of St. Louis, Washington, D.C., and Chicago illustrate the complexity of the problems involved.

St. Louis. Until I949, the use of city owned and operated outdoor swimming pools in St. Louis, Missouri, was denied to Negroes, although this segregation found "[n]o authority in ordinance, statute, or the Constitution of Missouri."II Responding to continued protests against this policy, ${ }^{12}$ the Director of Public Welfare decided in June I949, shortly before the beginning of the swimming season, that there was no legal basis on which the use of these pools could be denied to Negroes and announced that they would henceforth be open to all citizens regardless of race. ${ }^{13}$ Soon after the pools opened, Fairgrounds Park was the scene of a major disturbance in which a crowd of several hundred persons gathered and many Negroes were assaulted. ${ }^{14}$ The Mayor immediately ordered reimposition of the segregation policy. The St. Louis Council of Human Relations was created to study the problem and set up a program designed to win public acceptance of the use of all city-owned recreation facilities on a nonsegregated basis. The Director of the Mayor's Interracial Committee of Detroit, invited by the Council to study the situation, issued an extended report on the Fairgrounds Park riot ${ }^{15}$ in which he concluded that the step to break the segregation custom was taken too hastily. There had been none of the necessary advance planning with other government agencies and private groups, ${ }^{16}$ nor was it clear that the police were utilized effectively. ${ }^{17}$

${ }^{10}$ Although the unity of the enforcement problem is stressed here, for other purposes it may be important to distinguish the different contexts in which the law bears on segregation: (I) law which directly compels segregation, for example "Jim Crow" legislation; (2) law which directly forbids segregation, for example a great deal of civil rights legislation and situations in which the Fourteenth Amendment is construed so as to find segregation per se a denial of equal rights; and (3) areas in which the law appears to be neutral. "Neutrality" may take two forms. Legal relief may be denied to persons attacking the segregation or the emphasis may be on the denial of legal remedies to persons seeking to maintain segregation (as when the courts refuse to enforce restrictive covenants).

xs Draper v. St. Louis, 92 F. Supp. 546, 548 (E.D. Mo., I950).

12 Lawrence, Trial and Error in St. Louis, 86 Survey, No. I, at 13, I4 (Jan., I950); Schermer, The Fairgrounds Park Incident I6-I8 (July 27, I949).

${ }_{3}$ This was given prominent coverage in the local newspapers. St. Louis Globe Democrat (June 20, I949); St. Louis Post Dispatch, § A, p. 3, col. 5 (June 2I, I949).

${ }^{14}$ St. Louis Post Dispatch, § A, p. I, col. I (June 22, I949); Lawrence, op. cit. supra note I 2.

15 Schermer, The Fairgrounds Park Incident (July 27, 1949).

${ }^{16}$ Ibid., at $32-35$.

${ }^{27}$ It is difficult to evaluate the work of the St. Louis Police Department in the Fairgrounds Park disturbance. The Schermer report noted complaints about discriminatory police action. Ibid., at $24-26,30,35,39$. It was also stated that the police were given no advance notice of 
In April r950, the Council recommended that segregation be ended at two additional indoor swimming pools but that the opening of all other recreational facilities (notably the desirable outdoor pools) be accomplished gradually and only after an educational program had been conducted by the Council. In accepting its report, the Mayor stated to the Council that "[p]ublic safety demands the approach you have outlined."I8 In June, the outdoor pools opened for $195^{\circ}$, again segregated. In the same month, Negro citizens, denied admission to the pools solely because of their race, sought an injunction in the federal courts compelling the city to discontinue its segregation policy. The principal defense raised by the city was that its attempt to eliminate the segregation as "expeditiously as public feeling will permit" would "tend to prevent inter-racial friction." "In granting the injunction, Hulen, J., branded this contention "[a]s a proposition of law ... a new and novel theory" and stated that "[ $t]$ he law permits of no such delay in the protection of plaintiffs' constitutional rights." ${ }^{20}$

the decision to open the pools to Negroes at the beginning of the I949 season. Ibid., at 34 . The President of the St. Louis Board of Police Commissioners makes the same statement but goes on to say that the police were on notice in 1950 when a federal court injunction again ended the segregation. Communication from William Holzhausen, November I3, I95०. However, the decision to open the pools to Negroes in 1949 was publicized at least one full day before they were due to open. Nevertheless it was reported that early on the day of the opening there were only a few extra officers at the Fairgrounds Park pool, those having been sent by a district officer who thought there might be trouble. The day was filled with sporadic incidents reported to the police. Yet that evening, when a crowd of several hundred was gathered in front of the pool, there were only a dozen police officers on the scene. Schermer, op. cit. supra note II, at 22,27 .

As to whether the police had received adequate training in race relations problems, there is also conflicting evidence. Commissioner Holzhausen states that "[f]or several years, the Police Department in St. Louis has been laying heavy emphasis on the human relations factors involved in police work." He describes a series of panel discussions in an in-service training program in which representatives of local religious and public service organizations discuss "[i]n the frankest possible terms, the minorities in the community, a philosophy of dealing with them as well as the obligation of police in a free democratic society to treat and handle them regardless of race, national origin or any other presumably identifiable characteristics." Communication from William Holzhausen, November 13, r950. However, a staff member of the St. Louis Post Dispatch, writing of the Fairgrounds Park violence, concluded that the lack of proper training in race relations was an important factor in preventing full utilization of the police force in handling the disturbance. Lawrence, Trial and Error in St. Louis, 86 Survey No. I, at I3, I5 (Jan., I950). As to whether the training described by Commissioner Holzhausen is the type best calculated to enable police to handle racial violence, see text at notes $59^{-62}$ infra.

${ }^{8}$ St. Louis Post Dispatch, § A, p. 3, col. 8 (April $x_{5}$, r950).

x9 Draper v. St. Louis, 92 F. Supp. 546, 549 (E.D. Mo., $x_{95}^{\circ}$ ).

20 Ibid., at 549. The court held that the denial of publicly supported facilities to Negroes, solely because of their race, deprived them of their right to equal protection of the laws under the I4th Amendment and violated the Civil Rights Statute, 8 U.S.C.A. $\$ 43$.

The significance of the decision lay largely in the breadth of the reasoning with which a finding of discrimination was made. The defendants had testified as to the imminent completion of an outdoor pool which was to be opened to Negroes. The court, having already observed that the McLaurin case appeared to narrow the meaning of "substantial" in the "substantially equal" formula to a very fine line, stated that "[e]ven when completed such a pool may miti- 
On July Igth the injunction took effect and St. Louis' outdoor swimming pools were again unsegregated. ${ }^{2 x}$ For the rest of the summer, the pools remained open to all citizens and no major violence occurred. ${ }^{22}$ However, in order to prevent an outbreak, the police found it necessary to assign as many as 175 men to handle hostile crowds ranging up to $350 .{ }^{23}$ Early in August, when primary elections reduced the number of policemen available for this duty, the pools were closed for three days so as to prevent any disturbance. ${ }^{24}$ The pools were boycotted by their usual patrons. On a warm Sunday, when normally attendance at the Fairgrounds Park pool might have reached 4,000, there were I29 Negroes and twelve whites swimming. ${ }^{25}$ On July 3 oth, the St. Louis Post Dispatch reported that Negro men and boys, "[g]o to and from the pool between two lines of policemen, who face outward, separating the swimmers from a crowd of several hundred white men, women and children. Most of the whites make no secret of their hatred of what they regard as an intrusion. The policemen, backed by a fleet of motorcycles and scout cars, quickly shift position when necessary to head off sudden movements of the crowd." ${ }^{26}$

Washington. In June I949, Washington, D.C. was the scene of two days of sporadic fighting between Negroes and whites after an Interior Department order had re-affirmed a formal policy of non-segregation and after mixed groups attempted to enter a swimming pool previously used only by whites. ${ }^{27}$ Secretary Krug ordered the pool closed on the second day of violence and so it re-

gate discrimination, but it will not validate it as to other sections of the city." Draper v. St. Louis, 92 F. Supp. $546,55^{\circ}$ (E.D. Mo., I95o). The court found that the plaintiffs had shown no pecuniary loss to support a claim for compensatory and punitive damages. Ibid., at $55^{\circ}$.

2x The St. Louis Post Dispatch editorialized that the city's action for a last minute stay of execution before the injunction took effect "[s]eems to be evidence that it is little better prepared now than it was for the opening of the Fairgrounds Park pool in June of 1949." \& B, p. 2, col. 3 (July I8, I950).

${ }^{23}$ See generally the excellent coverage given by the St. Louis Post Dispatch, especially $\S \mathrm{A}$, p. I, col. 4 (July I9, r950); \& A, p. I, col. 4 (July 2I, I950); \& A, p. 3, col. 5 (July 22, r950); $\S$ A, p. 3, col. 6 (July 23, I950); \& A, p. 3 , col. 3 (July 24, r950); \& C, p. I, col. 2 (July 30, I950). ${ }_{23}$ Ibid., $\S$ A, p. 3, col. 4 (July 2I, I950); St. Louis Star Times (July 20, I950).

24 Representatives of the local NAACP were among those recommending the closing of the pools during elections. St. Louis Post Dispatch, § A, p. 3, col. 8 (July 28, 1950).

25 Ibid., \& A, p. 3, col. 3 (July 24, x950).

${ }^{26}$ Ibid., $\$$ C, p. I, col. 2 (July 30, I950). The President of the St. Louis Board of Police Commissioners states that a sizeable force was necessary only in the early stages of the situation to preserve order, and that the police detail was gradually reduced to a normal one at the pool. However, reserves were always standing by in the vicinity, subject to immediate call in the event of a disturbance. Communication from William Holzhausen, November 13, 1950. Mr. Holzhausen emphasizes the fact that the pool at Fairgrounds Park is located in a large recreational area which attracts several thousand persons on weekends. However, this also appears to be the case at Anacostia Park in Washington, D.C. where no sizeable police detail was found necessary in a similar situation. See text at notes 27-38 infra. Most importantly, there is no explanation as to why the St. Louis police did not attempt to disperse any crowds which gathered around the swimming pool.

${ }^{27}$ Washington (D.C.) Post, p. I, col. 2 (June 3o, x949). 
mained for the rest of the summer. Soon afterwards a race relations specialist was called in to discuss the problem of handling such disturbances with the Capital Parks police and Interior Department officials. ${ }^{28}$ Criticism of Secretary Krug's action was voiced in Congress where Representative Williams of Mississippi declaimed that "[ $t$ ]he Secretary ... had but to look to similar occurrences ... to know that such an order would bring bloodshed and race riots." And further: "I think that the Secretary is expecting a race riot as a result of his action in doing away with segregation at the swimming pools." ${ }^{29}$ Representatives Rankin of Mississippi, Davis of Georgia, and Hoffman of Michigan concurred..$^{\circ}$

In March I950, Secretary Chapman announced that the Anacostia pool, closed in 1949 because of racial disorders, would be reopened in $195^{\circ}$ to all citizens without any distinction. He went on to state that the Department of the Interior would be prepared to enforce the pool regulations by police action and protection if that became necessary. ${ }^{3 \mathrm{x}}$ Amid predictions of violence, ${ }^{32}$ arrangements were made for training the National Capital Parks police, pool personnel, and government officials in methods of handling racial tensions. Meanwhile, the Interior Department publicized its decision and emphasized the fact that the law would be enforced and that the policy of non-segregation was going to "stick." ${ }_{33}$ In June, before the pools opened, the Superintendent of the Washington Metropolitan police announced that he would back up the Capital Parks police in preserving order, even if that required using all of the men on his force. ${ }^{34}$

The results were in sharp contrast to the situation in St. Louis. There was no disorder throughout the summer, nor was it found necessary to station a large force of police at the pools to prevent an outbreak. ${ }^{35}$ Attendance at the pools

${ }^{8}$ Washington (D.C.) Post, § B, p. 2, col. I (August 8, I949).

${ }^{29} 95$ Cong. Rec. II230, II23I (I949).

${ }^{30}$ Reply to these charges and criticisms of the race relations consultant was later made by Representative Yates of Illinois. 95 Cong. Rec. 12003 (1949).

${ }^{31}$ Washington Post, § B, p. I, col. 8 (March 7, I950); Washington Star (March 9, I950).

${ }^{22}$ The Washington Post editorialized that the Interior Department could not operate the pools on a non-segregated basis "without provoking new racial tension and risking worse disorders than occurred last year" concluding that "[b]etter race relations are not fostered by dictation of rules that are certain to incite interracial animosities." $\$ \mathrm{~A}, \mathrm{p} .8$, col. I (April ro, I950).

33 Although the newspapers treated the Interior Department action as settling on a policy of non-segregation, the position of the Department was that there was no new policy involved, rather that the law which had no provision for segregation was to be enforced as it should have been in prior years.

34 Washington Post, § B, p. I, col. 6 (June 2, I950).

35 Edward Kelly, Superintendent of the Interior's National Capital Parks, announced in September his satisfaction with the absence of any disorder at the pools. Four policemen had been stationed at the Anacostia and East Potomac pools throughout the season, admittedly an increase over the usual number (one). Washington Post, § B, p. I, col. 8 (September 6, I950). 
did drop during $1950.3^{6}$ However, cold weather, a polio epidemic and the reluctance of parents to send their children swimming when violence was feared were seen as important contributing factors. ${ }^{37}$ Although the Washington Post had joined those predicting violence after Secretary Chapman's April statement, September found the Post glad to acknowledge its error and the success of the non-segregation policy. An editorial stated that the absence of any disorder was due in large part to effective police action and concluded that "[ $t]$ rouble is likely to arise only if, as was the case in I949, some organized group attempts to foment it." ${ }^{38}$

Chicago. Racial tensions run high in our society not only when people are competing for the use of public facilities, but also when jobs and housing are at stake. The Supreme Court's decision in the 1948 Restrictive Covenant cases $^{39}$ may have spelled an end to the support of racially segregated housing in the United States by legal sanctions..$^{\circ}$ If so, serious problems are raised about the extra-legal means which may be used to prevent Negroes from breaking out of tightly closed and overcrowded ghettos in cities like Chicago where the pattern of housing segregation is well established.4T

In Chicago, during November I949, the rumor that a Negro had purchased property in a "white" residential neighborhood near the notorious south side "black belt" was a factor in bringing about a riot in which a crowd of several hundred persons destroyed property and assaulted innocent individuals for five successive nights before being dispersed by the police..$^{42}$

Tension generated by the rumor erupted into violence on November 8th when a recently-settled resident on Peoria Street entertained in his home a

${ }^{36}$ At the Anacostia Park pool, attendance in 1948 was $112,447,35,626$ in 1949 (when the pool was open only for a short time before the disorders) and 28,000 in $195^{\circ}$ (including 16,000 Negroes and 12,000 whites).

Negroes had never made any attempt to use the East Potomac pool, located in a central non-residential section. Attendance at that pool in 1948 was $86,092,85,042$ in 1949 and 27,000 in $195^{\circ}$ (including 21,000 whites and 6,000 Negroes). Washington Star (September I6, I950).

37 Washington Post, \& M, p. 15, col. 4 (October I5, 1950).

${ }^{38}$ Ibid., $\$$ M, p. I2, col. 2 (September 10, 1950).

39 Shelley v. Kraemer, 334 U.S. I (I948); Hurd v. Hodge, 334 U.S. 24 (1948).

${ }^{\circ}$ Consult Ming, Racial Restrictions and the Fourteenth Amendment, The Restrictive Covenant Cases, r6 Univ. Chi. L. Rev. 203, 216-224 (r948).

4I Housing is particularly important because of the way in which it serves as the basis for other patterns of segregation (e.g., schools, social facilities) in communities where these are neither compelled nor permitted by law. See generally Weaver, The Negro Ghetto (I948).

42 Versions of the Peoria Street violence vary widely. An extended report was issued by the Chicago Commission on Human Relations (Dec. xo, 1949). The Commission, because of its position as an agency of the city government, has been criticized for a "conservative" attitude in these situations. The facts as here reported are therefore drawn largely from the Commission report, treating that report as a kind of "irreducible minimum" version of what actually happened. For examples of stronger criticism of the police and the Mayor, see Jack, Chicago's Violent Armistice, I69 Nation 57 I (Dec. IO, I949); Peters, Race War in Chicago, 122 New Republic, No. 2, at Io (Jan. 9, I950). 
group of visiting labor union officials and fellow union members, a group which included eight Negroes. A crowd gathered outside the home, protesting the presence of Negroes and threatening their white host. During the following four nights large crowds assembled in the area, no action being taken by the police to disperse them. During this time, the disturbance assumed an antiSemitic and anti-communist as well as an anti-Negro flavor. ${ }^{43}$ The property of the individual who had entertained Negroes in his home was damaged by the rioters who later turned to beating persons found in the area who were thought to be Jewish or were identified as "outsiders" and communists. On the fifth night of violence, after the crowd threatened to spill over onto a nearby business street, the police, who by that time had turned out in force under an emergency riot control plan, closed off the area and systematically attempted to disperse the mob.

Despite pressure from many private organizations and individuals during the rioting, the Mayor had refused to issue a statement. On November I8th, he made his first statement, blaming the disturbance on subversive groups, thus giving credence to the slogans of the rioters. ${ }^{44}$ Twelve days later this statement was "amplified" and Chicago's citizens were told that the "[p]olice have definite orders to disperse any crowd gathering for the purpose of harassing citizens" and that "[I]aw and order must and will be preserved in this community." $45 \mathrm{~A}$ circular from the Police Commissioner, dated December 2, r949, outlined procedures for immediately dispersing crowds gathered at a point of disorder..$^{46}$

There was strong criticism of the action of the city administration, particularly of the police department. ${ }^{47}$ Familiar complaints were voiced about discriminatory police action, in this instance based on evidence that some policemen were in direct sympathy with the mob..$^{8}$ Prominent among the demands made upon the Mayor after the riot was the recommendation that Chicago's Metropolitan Police receive training in the techniques for preventing

${ }^{43}$ The Chicago Daily News reported that "[a] policeman explained to one of our reporters that one batch [of persons] were properly beaten because they were Communists." "How do you know they were Communists?" the reporter inquired. "Because they were Jews," explained the policeman. \& I, p. 24, col. x (Nov. I6, I949).

44 Ibid., $\S$ x, p. 6, col. I (Nov. I8, I949).

45 Report of the Chicago Comm. on Human Relations 4 I (Dec. Io, I949).

${ }^{4} \mathrm{Ibid}$, at 42. Such incidents were not new to post-war Chicago. In I946, when Negroes moved into Airport Homes, a publicly owned and operated housing project, there was a major disturbance. In I947, a similar situation in the Fernwood community led to violence which was suppressed by one of the largest concentrations of police manpower ever seen in Chicago. Martin, Incident at Fernwood, 199 Harper's Magazine 86 (Oct., I949). A running account of attacks on property and individuals symptomatic of racial tensions is to be found in the monthly reports of the Chicago Commission on Human Relations in the section titled "Law and Order."

${ }^{47}$ See editorials in the Chicago Daily News, § I, p. 24, col. I (Nov. I6, I949); § I, p. 20, col. I (Dec. 2, 1949); Chicago Sun Times, p. 47, col. I (Nov. r8, 1949).

${ }^{48}$ Chicago Daily News, $\S$ I, p. 24, col. I (Nov. I6, I949); Report of the Chicago Commission on Fuman Relations, Appendix A (Dec. xo, r949); Jack, op. cit. supra note 42. 
future outbreaks of this kind. This was decided upon and early in I950 Professor Joseph Lohman, who had done similar work in Washington, D.C. after the I949 Anacostia Park disturbance, held several conferences with Chicago police captains and lieutenants. Significantly, the Mayor personally attended the first of these conferences, stated that another incident like Peoria Street must not be allowed to occur, and praised the work of Professor Lohman.49 It was announced that arrangements were being made for this training to reach all members of the force; ${ }^{50}$ however, it appears that this has not yet been done..$^{5 x}$

The immediate results of the police training, the policy of immediate dispersal of disorderly crowds, and the Mayor's statement indicate the importance of informed government action in situations where racial violence is a danger. Several incidents occurring during 1950 which might have developed into major violence were handled with dispatch by the officials concerned ${ }^{52}$ and, significantly, relations between the Chicago Commission on Human Relations and the police, almost at the breaking point during the Peoria Street riot, improved greatly. 53

While the complexity of these situations is such that no simple lessons are to be learned from them, they do suggest that the problem of racial violence can be effectively dealt with on a practical level. Responsible government officials must first of all decide to enforce relevant laws vigorously and protect the rights of individuals despite pressure from hostile members of the community. Equally important is skilled police work based on an understanding of the unique problems of predicting and preventing racial disorders.

\section{II}

After several American cities experienced major race riots during World War II, attention was focused on the problem of training police to prevent such violence. ${ }^{54}$ Several programs have been developed and used during the

49 Report of the Chicago Commission on Human Relations, Appendix C (March, I950).

so Ibid., $\mathrm{r}_{3}, \mathrm{r}_{4}$ (July, r950).

sx Communication from Joseph Lohman, January 15, I950.

${ }_{52}$ Memorandum from the Chicago Commission concerning an incident on April I6, I95\%; account in the Commission report for August 1950, Appendix A, of police dispersal tactics used in a south side neighborhood where Negro move-ins were followed by the gathering of potentially disorderly crowds; Chicago Sun-Times, p. 77, col. I (Dec. I7, $_{955}$ ).

53 During the Peoria Street riots, the Police Commissioner angrily refused to confer in the future with representatives of the Commission on Human Relations. Commission report 23 (Dec. IO, I949). Indications of the improvement are seen in the description of the working liaison now existing between the police and the Commission. Consult Commission reports: I4-I9 (July, I950); I4-I7 (Aug., I950).

54 Consult Int'l Ass'n of Chiefs of Police, Bulletin 5, Civil Disorders and Other Emergencies (July, I945) for discussion, from a police viewpoint, of the I943 Detroit race riot and other similar disturbances; J. T. Kluchesky, Understanding Attitudes Towards Minority Groups, address delivered at the $5^{2 \mathrm{~d}}$ annual conference of the Int'l Ass'n of Chiefs of Police; Lee, Race Riots Aren't Necessary (Pub. Affairs Pamphlet No. 107, 1945); Brown, Why Race Riots? (Pub. Affairs Pamphlet No. 87, 1945). 
past seven years, all designed to familiarize police agencies with the special methods needed to handle racial tension. 55 Although specific training techniques vary in content and emphasis, there is general agreement about the scope and objectives of police race relations training.

The first problem is raised by the existence of anti-minority group prejudice among the police themselves. Such prejudice is often behind discriminatory police action, ranging from systematic brutality ${ }^{56}$ to failure to protect the rights of minority groups. ${ }^{57}$ This is part of a vicious circle in which public confidence in the police as an impartial law enforcement agency is destroyed ${ }^{58}$ and the work of all police departments is made more difficult. Thus the police themselves often share responsibility for the aggravation of racial tensions within the community, and so the major objective of race relations training is the development of a professional and impartial attitude by the police officer.

One training approach takes the existence of prejudice as a point of departure and makes a direct attempt to change the personal attitudes of the police. ${ }^{59}$ In this view, law enforcement officers must be acquainted with such matters as the scientific facts about race differences and the practical meaning of a democratic ideology. A contrasting and preferable training approach assumes the existence of prejudice among the police but goes on to develop professional attitudes by relying on the hierarchical power structure typical of police and

ss Allport, Police and Minority Groups (Boston Police Dep't, r944); Interim Report of the Peace Officers Committee on Civil Disturbances (Cal. State Printing Office, 1943); McEntire and Powers, A Guide to Race Relations for Police Officers (Cal. State Printing Office, 1946); Weckler and Hall, The Police and Minority Groups (Int'l City Managers Ass'n, I944); Lohman, The Police and Minority Groups (I947).

During 1946 and $x 947$, the American Council on Race Relations distributed the manuals of Weckler and Hall and McEntire and Powers. ACRR also offered to interested communities Chief Kluchesky's services as a consultant in police human relations training.

For a summary treatment of the particular training programs used in major cities during the past five years, see Anti-Defamation League of the B'nai B'rith, Southern California, Regional Office, Study of Police Training Programs in Minority Relations, Appendix I (August, I950).

${ }^{6}$ Brutality is often the sanction with which policemen enforce certain extra-legal rules of race relations etiquette. Johnson, Patterns of Negro Segregation 32-35 (1943); Lohman, The Police and Minority Groups roI (I947).

57 This criticism almost invariably follows incidents of racial violence. See, e.g., White and Marshall, What Caused the Detroit Riot II-13, 29-36 (1943); Lee and Humphrey, Race Riot $73,74,76 \rightarrow 78$ (r943).

${ }^{8} \mathrm{McEntire}$ and Powers, A Guide to Race Relations for Police Officers 7, 24-26 (I946); Lee and Humphrey, Race Riot 73, 74 (I943); Fisher, The Problem of Violence, Observations on Race Conflict in Los Angeles 14 (1947).

59 See note 17 supra. The California training manual lists six requirements for the achievement of a professional attitude towards law enforcement problems in race relations by the police officer. Four of these appear to be part of an attempt to change the personal attitudes (prejudices) of the police officer; he must understand the psychology of race prejudice, the scientific facts about racial and cultural differences, the psychology of minority group behavior and the basic facts about the social and economic conditions under which minority groups live in the community. McEntire and Powers, A Guide to Race Relations for Police Officers I4 (I946). 
military organizations. ${ }^{60}$ Impartial conduct is demanded and obtained from the police officer first as a matter of discipline and secondly as a matter of professional pride. Here, as elsewhere, his duty as a public servant is to subordinate personal feelings to the performance of his duty. This approach avoids the difficult task of changing deeply rooted prejudices ${ }^{6 x}$ and has the advantage of using language and values which are particularly meaningful to members of any police force. ${ }^{62}$

Methods for predicting which situations in a community are likely to erupt into violence are effectively taught by an analysis of the kinds of social situations in which tension runs high. Similarly, the times and places at which violence is likely to occur can be predicted with a fair degree of accuracy. ${ }^{6}{ }^{6}$ With close liaison between police, other government agencies and interested private groups, it is possible to set up a highly efficient system for collecting and organizing information about the "trouble spots" which bear watching in the community. ${ }^{64}$

Being prepared to suppress violence is clearly not enough. Techniques for handling violence once it has broken out must be based on systematic preventive measures. ${ }^{65}$ Such tactics as the immediate dispersal of disorderly crowds, making a show of force when necessary and isolating danger spots are familiar parts of most riot control plans. ${ }^{66}$ Two facts serve to make racial violence unique in this connection: the possibility of predicting and preventing such violence and the peculiar importance of impartial conduct by members of the police force.

The police must be thoroughly acquainted with the law, both as to the rights

${ }^{60}$ One of the factors in the successful attacks on segregation in the Navy and the Air Force during the past two years has been identified as the "attitude of command." Report by the President's Committee on Equality of Treatment and Opportunity in the Armed Forces, Freedom to Serve 44 (1950). This presumably refers to the fact that in a military or quasimilitary organization orders tend to be obeyed when it is made clear that obedience is demanded.

6x Lohman, The Police and Minority Groups 6, 7, 8 (r947). With this approach, it has been possible to obtain the desired professional attitude even in police departments where the amount of anti-minority group prejudice is very great. Communication from Joseph Lohman, January 15,1950 .

62 See, however, Allport, Catharsis and the Reduction of Prejudice, I Journal of Social Issues, No. 3 , at 3 (Aug., I945) for different views about the possibility of directly affecting personal prejudices in such training situations. The distinction here made between training approaches refers to differences in emphasis rather than sharp divergences in method and content.

${ }^{63}$ Allport, The Police and Minority Groups 2-I4 (I944).

${ }^{64}$ The Chicago Commission on Human Relations now serves as a clearing-house for information on all local incidents symptomatic of racial tensions.

${ }^{65}$ McEntire and Powers, A Guide to Race Relations for Police Officers ro (I946). For a study of the effective use of preventive measures in several threatening situations during World War II, see Weckler and Hall, The Police and Minority Groups I-6 (1944).

${ }^{66}$ Wallman, Riots and Disorders, in The Police Yearbook $x 80$ (1940); Lohman, The Police and Minority Groups 75-92 (I947). 
of individuals and the scope of their enforcement powers. ${ }^{67}$ The "dead letter" of unenforced civil rights law is often unknown even to line officers. And emphasis on the scope of the arrest power in riot situations is frequently needed to meet police reluctance to make arrests in these cases. ${ }^{68}$

Training the police in race relations problems must be seen finally as part of the larger problem of professionalizing the status of police in the United States. ${ }^{69}$ The law enforcement officer should be treated as a trusted and responsible servant of the community whose work increasingly requires specialized knowledge and skills..$^{\circ}$ Given such recognition, an appeal to personal pride is quite as effective as reliance on discipline in obtaining impartial conduct from police personnel.

Properly trained, the police can become the key resource in any community program to prevent racial violence. However, improving the caliber of police work cannot be considered as an isolated problem. Nor should the responsibility of the police for the existence of racial tensions be exaggerated.

Responsible government officials must take a clear and well-publicized stand on the side of vigorous law enforcement. Such action by itself has often proved of value in alleviating racial tensions..$^{7 x}$ Discriminatory government action may be motivated by personal prejudices or by the belief that effective civil rights law enforcement is impossible. The use of familiar political techniques for channelizing pressures within the community is needed to effect change in such policies. It is especially important that the discussion emphasize that many of the supposed obstacles to vigorous law enforcement either do not exist or can be properly handled. Often, for example, widespread support for segregation is merely assumed when objective examination would reveal only a highly vocal minority pretending to speak as a majority. And to counter the violence threat, there is accumulated evidence that such danger is frequently more rhetorical than real.

The distinction between effective police action and vigorous law enforcement

${ }^{67}$ Ibid., at 95 ff.

${ }^{68}$ Fear of false arrest suits is often expressed by the police. However, reluctance to make arrests may be based directly on identification with elements in the community seeking to maintain segregation. Communication from Joseph Lohman, January 15, 1950.

${ }^{69}$ Lohman, The Police and Minority Groups 6 (I947). Gunnar Myrdal has stated the need for modern police training facilities in the South as a necessary step in the direction of changing the police in many southern communities from the enforcers of an extra-legal caste system to impartial public servants. Myrdal, An American Dilemma 535-545 (1944); Myrdal, Social Trends in America and Strategic Approaches to the Negro Problem, 9 Phylon 196, 209 (ro48). Steps have been taken in this direction, notably the opening of the Southern Police Institute at the University of Louisville in January, r95x. Louisville Courier Journal \&2, p. $x$, col. 8 (November I, I950).

${ }^{70}$ Consult Vollmer, The Police and Modern Society 235-237 (1936); Warren, The Police and Democracy, in The Police Yearbook I4, I8, I9 (1940); Greening, Report of the Committee on Professionalization of Police Service, in The Police Yearbook 20 (1939).

${ }^{7 x}$ Of the situations treated in this discussion, this was most strikingly true in Washington, D.C. during r950. Consult Weckler and Hall, The Police and Minority Groups I-6 (I944). 
efforts by other agencies of government is made only for the purpose of discussion. Actually the two appear to go together. It is clear, for example, that a decision to have the police receive necessary training in handling racial tensions is itself an indication that government officials are prepared to take other needed action in behalf of individual rights.

Racial tensions are but the symptoms of an underlying social pathology, consisting of widespread patterns of inequality at odds with our democratic credo..$^{72}$ Consequently, the prevention of violence as a matter of law enforcement is a much narrower problem than treatment of the causes of racial tension..$^{73}$

\section{III}

It is suggested that further investigation will bear out the hypothesis here advanced: that racial violence can be prevented even where the enforcement of civil rights law involves direct attack on established patterns of racial segregation. The key to such successful law enforcement is decisive and informed government action.

The rhetoric of violence has been an important part of the rationale of racial segregation in the United States; it has often swayed courts as well as legislatures. In this context, the violence threat appears not only as a possible obstacle to effective law enforcement but, what is more important, as one of the costs of eliminating segregation. There is the cost of violence which is not prevented, as well as the physical cost of preventive measures (as when a sizeable police force is found necessary) ${ }^{74}$ and the sacrifice of the psychological and economic stake which certain groups have in the status quo. On the other hand, there is evidence that most, if not all, racial violence can be prevented by well-advised government action. The expense of preventive measures may itself be due to delay and inefficiency in using them. And the disturbance of established expectations is a cost of any major social change. It is outweighed by the moral, psychological and economic costs connected with the institutions of segregation.

It is in this context that the soundness of the Draper v. St. Louis decision becomes clear. Judicial approval of racial segregation, based on the fear that recognition of a competing civil right would provoke costly violence, is unwise. The violence question is best decided by government officials responsible for law enforcement. Such judicial action is also undesirable since it reduces what should be a constant pressure on government to develop and utilize the most efficient techniques of law enforcement. If the danger of violence in any par-

72 The major thesis in Myrdal, An American Dilemma (1944). See especially c. I.

${ }^{73}$ Consult Drake and Cayton, Black Metropolis (1945).

74 Compare the policy of the London police department when post-war anti-Semitic riots found both communists and fascist organizations attempting to battle on the streets. West, Heil Hamm, 24 New Yorker at 24 (Aug. 7, 1948) and at 26 (Aug. x4, 1948). As to whether the duty of the state is the same even when the protection of individual rights would involve an extraordinary allocation of resources, it appears that the problem simply does not arise in such form. 
ticular case is so great as to constitute a major threat to the security of the community, the worst result will be a practical limitation on individual rights. Such unenforced civil rights law is not a new phenomenon. Its very existence emphasizes the importance of formally recognizing individual rights even where their immediate exercise is beset with practical difficulty. For only if this is done can citizens press for vigorous law enforcement.

Thirty-four years ago, in passing on the constitutionality of a municipal ordinance requiring residential segregation, the Supreme Court indicated what the attitude of the courts should be towards the question of racial violence.

It is urged that this proposed segregation will promote the public peace by preventing race conflict. Desirable as this is, and important as is the preservation of the public peace, this aim cannot be accomplished by laws or ordinances which deny rights created or protected by the Federal Constitution. ${ }^{75}$

Courts and legislatures, called upon to weaken further the institutions of segregation, may be reassured by substantial progress made since then in the arts of law enforcement and by important shifts in social sentiment.

The language of race relations discussion has shifted significantly during the past four decades. Waning in importance, but still important, are arguments based on the impossibility of "legislating social equality" and a supposed "right" to be prejudiced. ${ }^{6}$ Here, as elsewhere, ${ }^{77}$ social movement and the process of discussion have produced ever-changing formulations of the issues. Now it is said that there is no "right" to be prejudiced insofar as prejudice is expressed in overt acts which deprive other individuals of their rights. ${ }^{8}$ It is argued that few laws of any kind are ever made which do not conflict with the sentiments of some group in the community. ${ }^{79}$ And it is urged that legally sanctioned segregation has been a major cause of the prejudices which are said to make effective legal action impossible. ${ }^{80}$ Finally, as the functions of government in modern society expand, the role played by government agencies in race relations problems emerges as a central focus of debate. ${ }^{8 x}$

75 Buchanan v. Warley, 245 U.S. 60 , 8I (x9I7).

${ }^{76}$ Most of these notions have found their way into judicial discussions of segregation. See especially the Civil Rights Cases, Io9 U.S. 3 (I883); Plessy v. Ferguson, I63 U.S. 537, 55I, $55^{2}(1896)$.

77 Consult Levi, An Introduction to Legal Reasoning, I5 Univ. Chi. L. Rev. 501 (I948).

${ }^{8}$ Law and Discrimination, 4 New South, No. 9 at 4 (Sept., 1949).

79 Compare McWilliams, Race Discrimination and the Law, 9 Sci. \& Soc. I, I3, I4 (I944).

${ }^{80}$ See especially, Myrdal, An American Dilemma, "The Theory of the Vicious Circle" at 75-78 (I944), recalling Justice Harlan's famous phrase about permitting "the seeds of race hate to be planted under the sanction of law." Plessy v. Ferguson, I63 U.S. 537, 560 (I8g6).

${ }^{8 x}$ Compare the treatment of government action in Weaver, The Negro Ghetto (I948) with that in Ross, All Manner of Men (rg48) and Johnson, Patterns of Negro Segregation 323, 324 (x943). The broadened scope of governmental action is particularly important in the light of the "public-private" distinction which has limited the application of the Fourteenth Amendment. That the distinction is in the process of drastic redefinition, compare its treatment in the Restrictive Covenant Cases, 334 U.S. I (1948) with the eqtensions suggested by Ming, op. cit. supra note 40, and by the discussion in Race Discrimination in Housing, 57 Yale L.J. $426,456,457$ (1948). 
The change in rhetoric is never ending. However, the process serves to remind that exorcising the specter of racial violence is a matter of redefining the larger issues of freedom and equality as well as obtaining effective enforcement of civil rights law.

\section{THE NON-COMMUNIST AFFIDAVIT REQUIREMENT OF THE TAFT-HARTLEY ACT}

Recent developments have brought into focus the basic conflict which exists between the peculiar mechanism chosen by Congress to rid unions of Communist officers and the broader objectives of the amended National Labor Relations Act. ${ }^{x}$ Section 9(h) of that Act $^{2}$ denies the use of National Labor Relations Board facilities to unions whose officers fail to file non-Communist affidavits. ${ }^{3}$ Fundamental to the Act's objective of industrial harmony is the establishment of orderly procedures for enforcing the obligations it imposes upon employers. ${ }^{4}$ In applying Section $9(\mathrm{~h})$, the Board and the courts often must choose between sacrificing the collective bargaining principle and strengthening the position of union officers who fail to comply with the filing requirements. ${ }^{5}$

${ }_{49}$ Stat. 449 (I935), as amended, 6I Stat. $x_{36}$ (r947), 29 U.S.C.A. \$ 4 I (Supp., I95o). In upholding the constitutionality of the provision, the Supreme Court declared that the purpose of Congress was to eliminate the "political" strike. "Substantial amounts of evidence were presented to various committees of Congress ... that Communist leaders of labor unions had in the past and would continue in the future to subordinate legitimate trade union objectives to obstructive strikes when dictated by Party leaders, often in support of the policies of a foreign government." American Communications Ass'n, CIO v. Douds, 339 U.S. 382,388 (I950).

= Labor Management Relations Act of $1947, \S 9(\mathrm{~h})$, 6I Stat. r46 (1947), 29 U.S.C.A. \& I59(h) (Supp., I950).

3 The Section is one of three which require unions to report various types of information. Sections $g(f)$ and $g(g)$ require financial and organizational reports of unions seeking the use of NLRB machinery. 6I Stat. $1_{45}, 1_{46}$ (I947), 29 U.S.C.A. $\$ \S 1_{59}(\mathrm{f}), \mathrm{r}_{59}(\mathrm{~g})$ (Supp., $\mathrm{x}_{950}$ ). While attention in this note has been focused upon the non-Communist affidavit, most of the disabilities that attach to noncompliance refer as well to these other filing requirements.

1 The declaration of policy, for example, states that "[i]t is the purpose and policy of this Act, in order to promote the full flow of commerce, to prescribe the legitimate rights of both employees and employers in their relations affecting commerce, to provide orderly and peaceful procedures for preventing the interference by either with the legitimate rights of the other. . . ." Labor Management Relations Act of 1947 , \& I (b), 6I Stat. $x_{3} 6$ (r947), 29 U.S.C.A. $\$ 15$ I(b) (Supp., $x_{950}$ ).

$s$ Opponents of the measure early pointed out the nature of the conflict involved. In his message to Congress vetoing the Act, President Truman stated: "Such a union would have to win all its objectives by strike rather than by orderly procedure under the law. The union and the affected industry would be disrupted for perhaps a long period of time while violent electioneering, charges and counter-charges split open the union ranks. ... This provision in the bill is an attempt to solve difficult problems of industrial democracy by recourse to over-simplified legal devices." NLRB, Legislative History of the Labor Management Relations Act 921 ( $x_{948} 8$ ). Senator Morse stated: "We do not help the patriotic membership of [noncomplying] unions by requiring them to strike in order to protect the economic rights and benefits which other workers enjoy." Ibid., at $x, 559$. See also the remarks of Senator Murray, ibid., at $x, 049$. 